\title{
Challenges in diagnosis and treatment of sporadic inclusion-body myositis
}

\author{
Agata Sebastian ${ }^{1, A-F}$, Maria Misterska-Skóra ${ }^{1, A-F}$, Maciej Sebastian ${ }^{2, A-F}$, \\ Roksana Kręcichwost ${ }^{3, B-D}$, Katarzyna Haczkiewicz ${ }^{4, C, D}$ \\ 1 Department of Rheumatology and Internal Medicine, Faculty of Medicine, Wroclaw Medical University, Poland \\ ${ }^{2}$ Department of Minimally Invasive Surgery and Proctology, Faculty of Medicine, Wroclaw Medical University, Poland \\ ${ }^{3}$ Department of Ophthalmology, Faculty of Medicine, Wroclaw Medical University, Poland \\ ${ }^{4}$ Department of Histology and Embryology, Faculty of Medicine, Wroclaw Medical University, Poland \\ A - research concept and design; $\mathrm{B}$ - collection and/or assembly of data; $\mathrm{C}$ - data analysis and interpretation; \\ $\mathrm{D}$ - writing the article; $\mathrm{E}$ - critical revision of the article; $\mathrm{F}$ - final approval of the article
}

Address for correspondence

Agata Sebastian

E-mail:agatasebastian@vp.pl

Funding sources

None declared

Conflict of interest

None declared

Received on May 21, 2016

Reviewed on June 30, 2016

Accepted on March 27, 2017

\begin{abstract}
Sporadic inclusion body myositis (SIBM) is a rare yet increasingly prevalent disease and the most common cause of inflammatory myopathy in people over the age of 50 . The exact cause of the disorder is unknown. In sIBM 2 processes, first autoimmune and the other degenerative, parallelly occur in the muscle cells. The inflammation aspect is characterized by the cloning of $\mathrm{T}$ cells that appear to be driven by specific antigens to invade muscle fibers. The degeneration aspect is characterized by the appearance of holes in the muscle cell vacuoles, deposits of abnormal proteins within the cells and in filamentous inclusions. The disease has a major impact on patients' motor functionality and their quality of life. The treatment of sIBM still remains a major challenge. Early diagnosis of sIBM (already at the histopathology stage), when one still cannot observe fully developed clinical symptoms, may stop help to the progression of the disease.
\end{abstract}

Key words: biomarker, early diagnosis, sporadic inclusion body myositis

DOI

10.17219/acem/69855

\section{Copyright}

Copyright by Author(s)

This is an article distributed under the terms of the

Creative Commons Attribution Non-Commercial License

(http://creativecommons.org/licenses/by-nc-nd/4.0/) 
Table 1. Sporadic inclusion-body myositis (sIBM) diagnostic criteria from 2011

\begin{tabular}{|c|c|c|}
\hline Classification & Clinical features & Pathological features \\
\hline $\begin{array}{l}\text { Clinicopathologically } \\
\text { defined sIBM }\end{array}$ & $\begin{array}{l}\text { 1. duration of weakness }>12 \text { months } \\
\text { 2. creatine kinase } \leq 15 \times U L N \\
\text { 3. age at onset }>45 \text { years } \\
\text { 4. finger flexion weakness }>\text { shoulder abduction weakness, } \\
\text { and/or } \\
\text { 5. knee extension weakness }>\text { hip flexor weakness }\end{array}$ & $\begin{array}{l}\text { All of the following: } \\
\text { 1. endomysial inflammatory infiltrate } \\
\text { 2. rimmed vacuoles } \\
\text { 3. protein accumulation or } 15-18 \mathrm{~nm} \text { tubulofilaments }\end{array}$ \\
\hline Clinically defined sIBM & $\begin{array}{l}\text { 1. duration of weakness }>12 \text { months } \\
\text { 2. creatine kinase } \leq 15 \times \text { ULN } \\
\text { 3. age at onset }>45 \text { years } \\
\text { 4. finger flexion weakness }>\text { shoulder abduction weakness } \\
\text { 5. knee extension weakness }>\text { hip flexor weakness }\end{array}$ & $\begin{array}{l}\text { One or more: } \\
\text { 1. endomysial inflammatory infiltrate } \\
\text { 2. upregulation of } \mathrm{MHC} \text { class I } \\
\text { 3. rimmed vacuoles } \\
\text { 4. protein accumulation or } 15-18 \mathrm{~nm} \text { tubulofilaments }\end{array}$ \\
\hline Probable sIBM & $\begin{array}{l}\text { 1. duration of weakness }>12 \text { months } \\
\text { 2. creatine kinase } \leq 15 \times U L N \\
\text { 3. age at onset }>45 \text { years } \\
\text { 4. finger flexion weakness }>\text { shoulder abduction weakness, } \\
\text { or } \\
\text { 5. knee extension weakness }>\text { hip flexor weakness }\end{array}$ & $\begin{array}{l}\text { One or more: } \\
\text { 1. endomysial inflammatory infiltrate } \\
\text { 2. upregulation of } \mathrm{MHC} \text { class I } \\
\text { 3. rimmed vacuoles } \\
\text { 4. protein accumulation or } 15-18 \mathrm{~nm} \text { tubulofilaments }\end{array}$ \\
\hline
\end{tabular}

sIBM - sporadic inclusion body myositis; MHC class I - major histocompatibility complex class I; ULN - upper limit of normal.

Sporadic inclusion-body myositis (sIBM) is one of the causes of myopathy that should be considered in rheumatological and neurological diagnosis. The onset of the disease is usually concealed and clinical symptoms develop slowly (over the years), leading to weakness and atrophy of both proximal and distal muscles. ${ }^{1}$ The term sIBM was introduced in 1971 by Yunis and Samaha to describe patients with polymyositis, for whom the histopathological examination revealed the presence of rimmed vacuoles and specific intercalations localized in the cytoplasm and nuclei of muscle fibers. ${ }^{1,2}$ Generally, sIBM is taken into consideration in the diagnosis of myopathy when a patient does not respond to the treatment with glucocorticosteroids, or when the clinical symptoms include muscle involvement seen in distal muscles, particularly in the foot extensors or deep fingers flexors. ${ }^{1-4}$ Moreover, the facial and swallowing muscles are affected; hence, one of the clinical symptoms of sIBM could be difficulty in swallowing. ${ }^{5}$ The disease usually manifests itself after the age of 50 and is more common among males (2:1). Its steady progress leads to significant motor impairment. The muscle involvement can be asymmetric and can occur selectively in the quadriceps (muscles of the thighs), iliopsoas muscle, triceps, biceps, and forearm flexor muscles. ${ }^{5}$ Laboratory tests may show elevated or normal levels of creatine kinase (CK). Asymptomatic presentation of sIBM is rare. ${ }^{6}$

Electromyography (EMG) can be used to exclude typical causes of neurogenic disorders and to classify the disease into the group of muscle damage; however, it cannot accurately extract its cause (myositis, toxic or dystrophic myopathic processes). ${ }^{5}$ Therefore, muscle biopsy with histopathologic, immunohistochemical and microscopical examination remains the best method for diagnosing sIBM. In the analysis of the muscle biopsy, sIBM can be signalized by: inflammatory infiltrations, infiltration
Table 2. Sporadic inclusion-body myositis (sIBM) diagnostic criteria from 1995

\begin{tabular}{|c|c|}
\hline $\begin{array}{l}\text { Clinical } \\
\text { features }\end{array}$ & $\begin{array}{l}\text { 1. duration of illness }>6 \text { months } \\
\text { 2. age of onset }>30 \text { years old } \\
\text { 3. muscle weakness affecting proximal and distal } \\
\text { muscles of arms and legs and patient must exhibit at } \\
\text { least } 1 \text { of the following features: } \\
\text { a. finger flexion weakness } \\
\text { b. wrist flexion weakness }>\text { wrist extension weakness } \\
\text { c. quadriceps muscle weakness ( } \leq \text { grade } 4 \text { MRC) }\end{array}$ \\
\hline $\begin{array}{l}\text { Laboratory } \\
\text { features }\end{array}$ & $\begin{array}{l}\text { 4. serum creatine kinase }<12 \text { times normal } \\
\text { 5. muscle biopsy } \\
\text { a. inflammatory myopathy characterized } \\
\text { by mononuclear cell invasion of non-necrotic } \\
\text { muscle fibers } \\
\text { b. vacuolated muscle fibers } \\
\text { c. either intracellular amyloid or } 15-18 \mathrm{~nm} \\
\text { tubulofilaments } \\
\text { 6. electromyography - inflammatory myopathy }\end{array}$ \\
\hline
\end{tabular}

MRC - Medical Research Council scale.

of inflammatory cells intact muscle fibers (partial infiltration), rimmed vacuoles, deposits of amyloid, and 15-18 nm tubulofilaments seen in electron microscopy. Moreover, it should be noted that not all of these changes can be observed in every patient simultaneously; this fact is included in the diagnostic criteria from 2011 (Table 1). ${ }^{7}$ So far, the existing diagnostic criteria for sIBM have been mainly based on histopathological changes (Table 2). ${ }^{7}$ In definite IBM, patients must exhibit all muscle biopsy features, including invasion of non-necrotic fibers by mononuclear cells, vacuolated muscle fibers and intracellular (within muscle fibers) amyloid deposits or 15-18 nm tubulofilaments. If the muscle biopsy shows only inflammation (invasion of non-necrotic muscle fibers by mononuclear cells) without other pathological features of IBM, then a diagnosis of possible IBM can be given if the patient exhibits the characteristic clinical and laboratory features. 

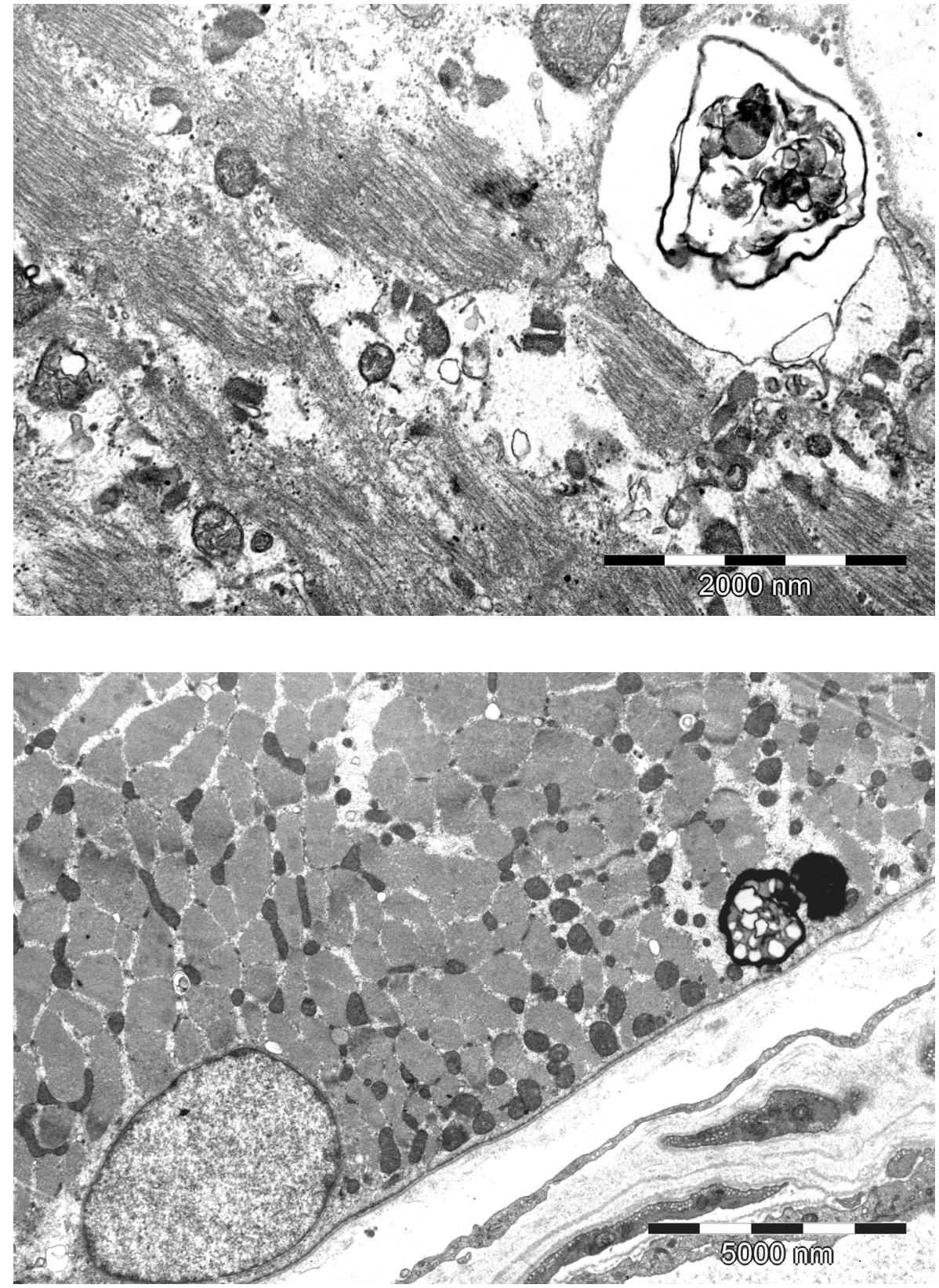

Fig. 1A. Myelin structure, transmission electron microscopy (TEM)

\section{Prognostic factors in sporadic inclusion body myositis}

The disease has a major impact on the patients' motor functionality and their quality of life. As the time of disease development is slow, the survival rate of patients with sIBM is probably not comparable to the life expectancy of the general population. ${ }^{8}$ Causes of death associated with IBM mainly include malnutrition, wasting (cachexia), aspiration, respiratory infections as a result of dysphagia, and decreased respiratory muscle function in advanced cases of the disease. ${ }^{7}$ The increased cancer risk was not proven like in other inflammatory myositis. ${ }^{9}$ According to Benveniste et al., a few factors can contribute to the progression of the disease towards disability and they include: male gender, older age ( $>60$ years) and immunosuppressive therapy. ${ }^{10}$ Cortese et al. also suggested that advanced age
(>55 years) is associated with an unfavorable prognosis. ${ }^{11}$ Furthermore, the time to stand up and start the movement was the prognostic factor in patients with sIBM. ${ }^{12}$

The cause of the disease is still not fully understood. So far, the proposed theories suggest a role in the etiology of disease of: viral infection, accumulation of toxic proteins, the autoimmune attack, degeneration of muscle cells (rimmed vacuoles filled with nuclear and lysosomal proteins, and inclusions in the cytoplasm of muscle cells composed of the TDP-43 (TAR DNA-binding protein 43) (Fig. 1A,B); the role of lysosomal membrane protein LAMP1 and LAMP2 in the degeneration of the muscle cells' proteins and the formation of typical vacuole), and impaired proteasome and autophagocytosis function (accumulation of P62 (a protein associated with the nuclear pores-lamin involved in the transportation between the nucleus and cytoplasm), LC3 (microtubule-associated proteins 1A/1B 
light chain 3-autophagy membranes) and NBR1 (neighbor of the $B R C A 1$ gene 1 protein, receptor associated with P62)) ${ }^{5,13-15}$ New insights into the role of p62 in sIBM pathogenesis indicate that $\mathrm{p} 62$ join to perform selective autophagy ${ }^{16}$ Furthermore, p62 could be induced by some cellular stresses. Nakano et al. recently published the theory that in sIBM, compromised binding of the p62-ubiquitinated protein complex to LC3 could stop the autophagy process in its initial stages, which causes the formation of aggregates of p62-oligomers with Lys63-ubiquitinated proteins. ${ }^{16}$ Also, the upregulation of TGF- $\beta$ (transforming growth factor- $\beta$ ) signaling may have an important influence on sIBM pathogenesis. ${ }^{17}$

Among patients with sIBM, the histopathological muscle biopsy finds: atrophied fibers along with the normal and overgrown fibers with properly preserved differentiation in the types of metabolic, infiltration with mononuclear cells (mainly lymphocytes around blood vessels and muscle fibers that do not show the features of necrosis), presence of rimmed vacuoles in the fibers and eosinophils inclusions in the cytoplasm of muscle fibers, as well as vacuoles comprising basophilic granularities. ${ }^{7,18}$

The fact that sIBM belongs to the group of autoimmune diseases is indicated by the presence of infiltrates composed of cytotoxic lymphocytes $\mathrm{T} \mathrm{CD} 8^{+}$that form an immunological connection with major histocompatibility complex class I (MHC-I). This leads to a failure of muscle fibers through the mechanism of special cytolytic proteins-perforins, which provides the reason for the use of immunosuppressive drugs. ${ }^{19-25}$ Additionally, apart from the inflammatory process, in sIBM coexist features of the degeneration of muscle fibers in the form of rimmed vacuoles, and the depositions of congophilic amyloids and other specific proteins..$^{21}$ Rare missense variants in FYCO1 (a protein accumulated at rimmed vacuoles) may impair autophagic function, leading to rimmed vacuoles formation. ${ }^{26}$ In sIBM there were also observed activated lymphocytes of B type, dendritic cells of plasmacytoid origin in the area of perivascular and perimysium, as well as increased expression of adhesion molecules and significant amount of cytokines and chemokines such as, for example: $\gamma$-interferon, interleukin (IL)-1b, tumor necrosis factor alpha (TNF- $\alpha$ ), CXCL3-CXCL10, and deregulated expression of mitochondrial proteins in oxidative phosphorylation. ${ }^{13,27}$ Still, there are no established biomarkers for SIBM that could be used in everyday clinical practice. ${ }^{28}$ The proposed biomarkers of the disease are presented in Table 3 . The determination of biomarkers of sIBM is limited by the lack of specific standards for the use of specific biomarkers (medium cut, accountability), the lack of comparable sensitivity and specificity with other than sIBM muscle diseases, and the need to perform invasive muscle biopsy. Nowadays, the most suitable determination method appears to be the use of antigens anti-cN1A (cytosolic 5'-nucleotidase 1A antibodies), described for the first time by Larman et al. ${ }^{29}$ The antigen localizes itself predominantly in the
Table 3. The biomarkers of sporadic inclusion-body myositis (sIBM)

\begin{tabular}{|c|c|}
\hline Biomarker & Mechanism of action \\
\hline $\begin{array}{l}\text { Rimmed vacuoles (1.3-16\% of muscle } \\
\text { fibers in IBM) }\end{array}$ & degeneration of muscle cells \\
\hline Tubulofilaments & $\begin{array}{l}\text { theory of viral infection - } \\
\text { unconfirmed }\end{array}$ \\
\hline Congo red-stained material & protein accumulation \\
\hline $\begin{array}{l}\text { Beta-amyloid accumulation (6-25\% } \\
\text { of patients with IBM) }\end{array}$ & theory of molecular toxicity \\
\hline $\begin{array}{l}\text { TDP-43 accumulation (inside and } \\
\text { around rimmed vacuoles, sensitivity - } \\
91 \% \text { and specificity - } 77 \% \text { vs } 0 \% \text { and } \\
8 \% \text { in polymiosyositis) }\end{array}$ & $\begin{array}{l}\text { metabolism of nucleic acids, } \\
\text { degeneration of muscle cells }\end{array}$ \\
\hline $\begin{array}{l}\text { Immunoreactive SMI-31 } \\
\text { accumulations (initially named } \\
\text { phosphorylated tau protein) }\end{array}$ & unknown \\
\hline p62 accumulation & $\begin{array}{l}\text { protein accumulation, } \\
\text { autophagocytosis }\end{array}$ \\
\hline cN1A antibodies & metabolism of nucleic acids \\
\hline Invasion of nonnecrotic fibers & autoimmune etiology \\
\hline $\begin{array}{l}\text { BACE-1 } \\
\text { PS-1 } \\
\text { SAPP }\end{array}$ & $\begin{array}{l}\text { amyloidogenic-related } \\
\text { molecules }\end{array}$ \\
\hline
\end{tabular}

BACE-1 - beta-secretase-1; PS-1 - presenilin-1; SAPP $\beta$ - soluble A $\beta$ precursor protein

perinuclear and rimmed vacuoles region. Their advantage is the determination of blood serum taken from patients. Their sensitivity was between $60 \%$ and $70 \%$ and specificity was enclosed in the range of $83-92 \%$ at low titer and correspondingly $33-34 \%$ and $96-98 \%$ at high titer. ${ }^{29-32}$ Probably, this antibody could be connected with a more severe phenotype and a higher adjusted mortality risk..$^{33}$

Treatment of sIBM still remains a major challenge due to the coexistence of autoinflammatory and degenerative processes. So far, there has not been enough evidence in favor of using glucocorticosteroids, methotrexate, cyclosporine, azathioprine, mycophenolate mofetil, or intravenous immunoglobulin. Even though up to $30 \%$ of patients during the initial period of treatment may show some response, the disease is still slowly progressing. ${ }^{21,34,35}$ Recently, it was suggested that the aggressive anti-inflammatory treatment in sIBM might stop the degenerative process. Therefore, a few studies were carried out with the use of alemtuzumab (humanized monoclonal IgG1 kappa causing long-term reduction in lymphocytes). Indeed, the results showed that this antibody significantly reduces the number of $\mathrm{T}$ cells in the muscles and inhibits certain molecules associated with degenerative process, which slowed down the progression of the disease in the 6-month period under consideration. However, there was no improvement in muscle strength. ${ }^{36,37}$ Other substance, arimoclomol, has been already used in neurology as it affects the expression of the heat shock proteins (HSP). In the course of therapy, slow improvement was observed in patients' exercise capacity, assessment of manual muscle (MMT) and grip strength in the right upper extremity. However, no effect was found 
on the quantitative assessment of muscle tissue with dual-energy X-ray absorptiometry (DEXA) and the level of HSP70 in the muscle biopsy taken at the beginning and at the end of the treatment. The study in question has yet to be fully published. ${ }^{38}$ Currently, we are expecting the results from 2 other studies that were carried out with the administration of rapamycin..$^{21,39,40}$ The research that was carried out with the use of immunosuppressive drugs represents an introduction to new treatment options and a better understanding of sIBM's pathomechanism. Early diagnosis of sIBM (already at the histopathological stage), when one still cannot observe fully developed clinical symptoms, may help to stop the progression of the disease.

\section{References}

1. Dalakas MC. Immunotherapy of inflammatory myopathies: Practical approach and future prospects. Curr Treat Options Neurol. 2011;13(3): 311-323.

2. Yunis EJ, Samaha FJ. Inclusion body myositis. Lab Invest. 1971;25(3): 240-248.

3. Hausmanowa-Petrusewicz I. Choroby nerwowo-mięśniowe. $2^{\text {nd }}$ ed. Lublin, Poland: Czelej; 2013.

4. Kobayashi Z, Fukatsu E, Itaya S, et al. Fist sign in inclusion body myositis. Neuromuscul Disord. 2017;27(4):385-386.

5. Dalakas MC. Therapeutic advances and future prospects in immunemediated inflammatory myopathies. TherAdv NeurolDisord. 2008;1(3): 157-166.

6. Bello R, Bertorini T, Ganta K, Mays W. A Case of asymptomatic inclusion body myositis. J Clin Neuromuscul Dis. 2017;18(3):132-134.

7. Machado P, Brady S, Hanna MG. Update in inclusion body myositis. Curr Opin Rheumatol. 2013;25(6):763-771.

8. Price MA, Barghout V, Benveniste $O$, et al. Mortality and causes of death in patients with sporadic inclusion body myositis: Survey study based on the clinical experience of specialists in Australia, Europe and the USA. J Neuromuscul Dis. 2016;3(1):67-75.

9. Molberg $\varnothing$, Dobloug $C$. Epidemiology of sporadic inclusion body myositis. Curr Opin Rheumatol. 2016;28:657-660.

10. Benveniste $O$, Guiguet M, Freebody J, et al. Long-term observational study of sporadic inclusion body myositis. Brain. 2011;134(Pt 11): 3176-3184.

11. Cortese A, Machado P, Morrow J, et al. Longitudinal observational study of sporadic inclusion body myositis: Implications for clinical trials. Neuromuscul Disord. 2013;23(5):404-412.

12. Jørgensen AN, Aagaard P, Nielsen JL, et al. Physical function and muscle strength in sporadic inclusion body myositis. Muscle Nerve. 2017;56(6):50-58. doi: 10.1002/mus.25603

13. Kumamoto T, Ueyama H, Tsumura H, Toyoshima I, Tsuda T. Expression of lysosome-related proteins and genes in the skeletal muscles of inclusion body myositis. Acta Neuropathol. 2004;107(1):59-65.

14. Kumamoto T, Ueyama H, Watanabe $\mathrm{S}$, Kominami E, Ando M. Muscle fiber degradation in distal myopathy with rimmed vacuoles. Acta Neuropathol. 1994;87(2):143-148.

15. Rothwell S, Cooper RG, Lamb JA, Chinoy H. Entering a new phase of immunogenetics in the idiopathic inflammatory myopathies. Curr Opin Rheumatol. 2013;25(6):735-741.

16. Nakano S, Oki M, Kusaka H. The role of p62/SQSTM1 in sporadic inclusion body myositis. Neuromuscul Disord. 2017;27(4):363-369. doi: 10.1016/j.nmd. 2016.12.009

17. Noda $S$, Koike $H$, Maeshima $S$, et al. Transforming growth factor- $\beta$ signaling is upregulated in sporadic inclusion body myositis. Muscle Nerve. 2017;55(5):741-747. doi: 10.1002/mus.25405

18. Gallay L, Petiot P. Sporadic inclusion-body myositis: Recent advances and the state of the art in 2016. Rev Neurol (Paris). 2016;172(10):581-586.
19. Dalakas MC. Mechanisms of disease: Signaling pathways and immunobiology of inflammatory myopathies. Nat Clin Pract Rheumatol. 2006;2(4):219-227.

20. Dalakas MC. An update on inflammatory and autoimmune myopathies. Neuropathol App/ Neurobiol. 2011;37(3):226-242.

21. Dalakas MC. Inflammatory myopathies: Management of steroid resistance. Curr Opin Neurol. 2011;24(5):457-462.

22. Rygiel KA, Tuppen HA, Grady JP, et al. Complex mitochondrial DNA rearrangements in individual cells from patients with sporadic inclusion body myositis. Nucleic Acids Res. 2016;44(11):5313-5329.

23. Hohlfeld R, Schulze-Koops H. Cytotoxic T cells go awry in inclusion body myositis. Brain. 2016;139(Pt 5):1312-1314.

24. Greenberg SA. Inclusion body myositis. Continuum (Minneap Minn). 2016;22(6, Muscle and Neuromuscular Junction Disorders):1871-1888.

25. Bhattarai S, Ghannam K, Krause S, et al. The immunoproteasomes are key to regulate myokines and $\mathrm{MHC}$ class I expression in idiopathic inflammatory myopathies. J Autoimmun. 2016;75:118-129.

26. Güttsches AK, Brady S, Krause K, et al. Proteomics of rimmed vacuoles define new risk allele in inclusion body myositis. Ann Neurol. 2017;81(2):227-239.

27. Catalán-García M, Garrabou G, Morén C, et al. Mitochondrial DNA disturbances and deregulated expression of oxidative phosphorylation and mitochondrial fusion proteins in sporadic inclusion body myositis. Clin Sci (Lond). 2016;130(19):1741-1751.

28. Catalán-García M, Garrabou G, Morén C, et al. BACE-1, PS-1 and sAPPß levels are increased in plasma from sporadic inclusion body myositis patients: Surrogate biomarkers among inflammatory myopathies. Mol Med. 2015;21(1):817-823. doi: 10.2119/molmed.2015.00168

29. Larman BH, Salajegheh M, Nazareno R, et al. Cytosolic 5'-nucleotidase $1 \mathrm{~A}$ autoimmunity in sporadic inclusion body myositis. Ann Neurol. 2013;73(3):408-418.

30. Pluk H, van Hoeve BJ, van Dooren $\mathrm{SH}$, et al. Autoantibodies to cytosolic 50-nucleotidase 1A in inclusion body myositis. Ann Neurol. 2013;73(3):397-407.

31. Greenberg SA. Cytoplasmic 5'-nucleotidase autoantibodies in inclusion body myositis: Isotypes and diagnostic utility. Muscle Nerve. 2014;50(4):488-492.

32. Kramp SL, Karayev D, Shen G, et al. Development and evaluation of a standardized ELISA for the determination of autoantibodies against CN-1A (Mup44, NT5C1A) in sporadic inclusion body myositis. Auto Immun Highlights. 2016;7(1):16.

33. Lilleker JB, Rietveld A, Pye SR, et al.; all UKMYONET contributors. Cytosolic 5'-nucleotidase $1 \mathrm{~A}$ autoantibody profile and clinical characteristics in inclusion body myositis. Ann Rheum Dis. 2017;76(5):862-868. doi: 10.1136/annrheumdis-2016-210282

34. Mowzoon N, Sussman A, Bradley WG. Mycophenolate (CellCept) treatment of myasthenia gravis, chronic inflammatory polyneuropathy and inclusion body myositis. J Neurol Sci. 2001;185(2):119-122.

35. Keck AD, Walker UA. Therapy of myositis [in German]. Z Rheumatol. 2013;72(3):227-235.

36. Dalakas MC, Rakocevic G, Schmidt J, et al. Effect of alemtuzumab (CAMPATH 1-H) in patients with inclusion-body myositis. Brain. 2009;132(6):1536-1544.

37. Schmidt K, Kleinschnitz K, Rakocevic G, Dalakas MC, Schmidt J. Molecular treatment effects of alemtuzumab in skeletal muscles of patients with IBM. BMC Neurol. 2016;16:48.

38. Machado P, Miller A, Herbelin L, et al. Safety and tolerability of arimoclomol in patients with sporadic inclusion body myositis: A randomized, double-blind, placebo-controlled, phase IIA proof-of-concept trial. Ann Rheum Dis. 2013;72:164.

39. Ching JK, Weihl CC. Rapamycin-induced autophagy aggravates pathology and weakness in a mouse model of VCP-associated myopathy. Autophagy. 2013;9(5):799-800.

40. Ahmed M, Machado PM, Miller A, et al. Targeting protein homeostasis in sporadic inclusion body myositis. Sci Transl Med. 2016;8(331): 331-341. 